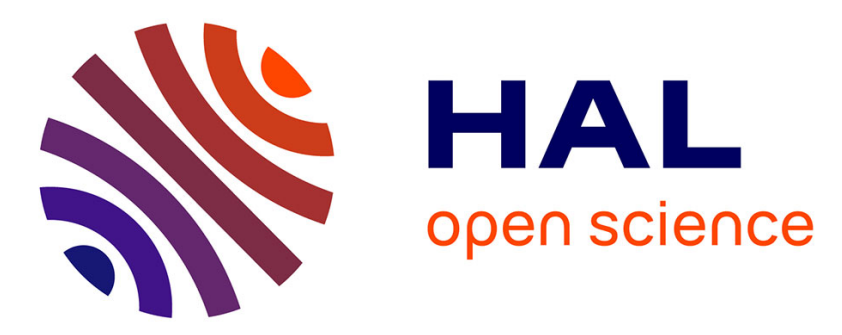

\title{
Fluorescence characteristics of chromophoric dissolved organic matter in shallow water along the Zhejiang coasts, southeast China
}

\author{
Lei Gao, Daidu Fan, Daoji Li, Jingong Cai
}

\section{- To cite this version:}

Lei Gao, Daidu Fan, Daoji Li, Jingong Cai. Fluorescence characteristics of chromophoric dissolved organic matter in shallow water along the Zhejiang coasts, southeast China. Marine Environmental Research, 2010, 69 (3), pp.187. 10.1016/j.marenvres.2009.10.004 . hal-00565111

HAL Id: hal-00565111

https://hal.science/hal-00565111

Submitted on 11 Feb 2011

HAL is a multi-disciplinary open access archive for the deposit and dissemination of scientific research documents, whether they are published or not. The documents may come from teaching and research institutions in France or abroad, or from public or private research centers.
L'archive ouverte pluridisciplinaire HAL, est destinée au dépôt et à la diffusion de documents scientifiques de niveau recherche, publiés ou non, émanant des établissements d'enseignement et de recherche français ou étrangers, des laboratoires publics ou privés. 


\section{Accepted Manuscript}

Fluorescence characteristics of chromophoric dissolved organic matter in shallow water along the Zhejiang coasts, southeast China

Lei Gao, Daidu Fan, Daoji Li, Jingong Cai

PII:

S0141-1136(09)00130-5

DOI:

10.1016/j.marenvres.2009.10.004

Reference:

MERE 3379

To appear in:

Marine Environmental Research

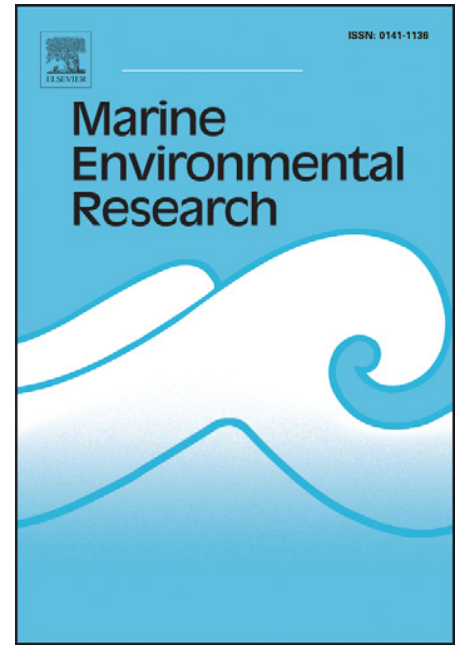

Received Date: $\quad 12$ December 2008

Revised Date: $\quad 1$ October 2009

Accepted Date: $\quad 7$ October 2009

Please cite this article as: Gao, L., Fan, D., Li, D., Cai, J., Fluorescence characteristics of chromophoric dissolved organic matter in shallow water along the Zhejiang coasts, southeast China, Marine Environmental Research (2009), doi: 10.1016/j.marenvres.2009.10.004

This is a PDF file of an unedited manuscript that has been accepted for publication. As a service to our customers we are providing this early version of the manuscript. The manuscript will undergo copyediting, typesetting, and review of the resulting proof before it is published in its final form. Please note that during the production process errors may be discovered which could affect the content, and all legal disclaimers that apply to the journal pertain. 
1

2

3

4

5

6

7

8

9

(1)

Fluorescence characteristics of chromophoric dissolved organic matter in shallow water along the Zhejiang coasts, southeast China

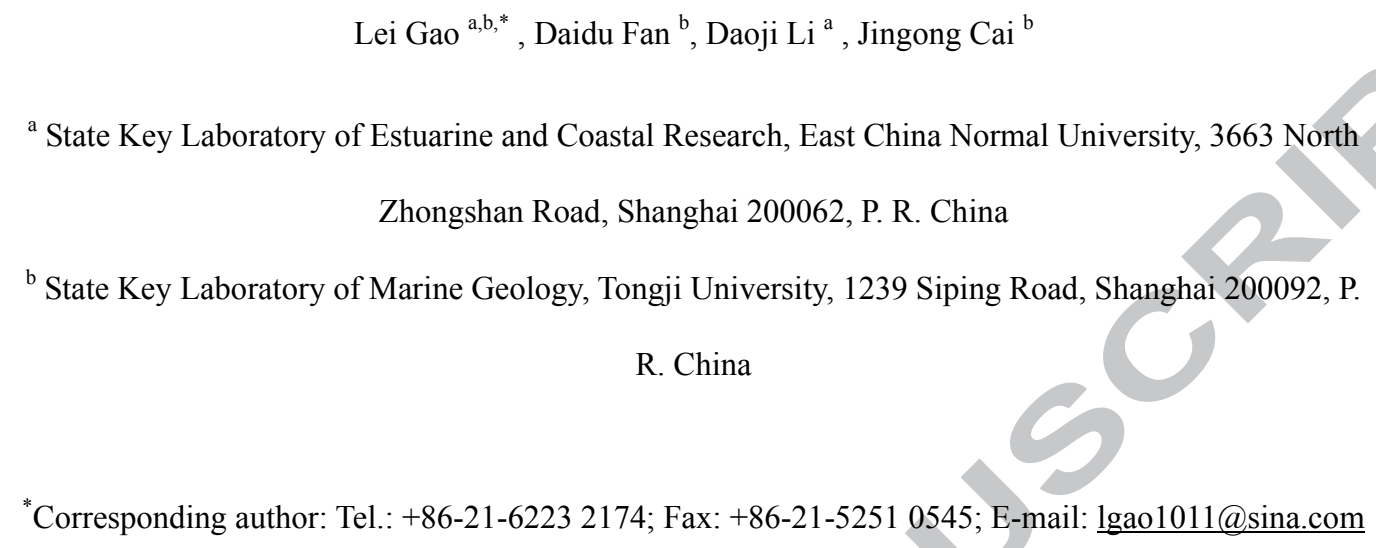

Abstract: Twenty-eight surface water samples from rivers, muddy intertidal flats, sand shores, and bedrock coasts were collected along the Zhejiang coastline in southeastern China. In addition, three samples from the Changjiang (Yangtze River) were collected for comparison. CDOM (chromophoric dissolved organic matter) absorption and fluorescence excitation-emission matrix (EEM) spectroscopy, as well as nutrients and DOC were measured in these samples. According to salinity, nutrient, and DOC constituents, the 28 Zhejiang samples were categorized into four groups, i.e. highly-polluted, river derived, muddy-flat derived, and saltwater dominated ones. Among the six parameters (two humic-like and two protein-like peak intensities in fluorescence EEM contours, absorption at $300 \mathrm{~nm}$, and DOC concentration) for the Zhejiang samples, any two of them were positively correlated. The submarine groundwater discharge, rather than local rivers, might have provided most of the freshwater that interacted with the saltwater during the mixing process. The high protein-like EEM peaks in samples from muddy salt marshes and rivers were probably caused by terrestrial inputs, land-based pollution, and local biological activities in combination.

Keywords: fluorescence spectroscopy; biogeochemical cycle; pollution effects; submarine groundwater discharge; salt marshes; coastal waters; East China Sea

1. Introduction: 
Chromophoric dissolved organic matter (CDOM), absorbing light in the UV-visible range, represents one important fraction of dissolved organic mater (DOM) pool (Coble, 2007). Excitation-emission matrix (EEM) spectroscopy of CDOM has been applied for characterizing fluorescence properties of DOM in recent decades (Coble et al., 1990; Mopper and Schultz, 1993). This technique yields important information on the dynamics and chemical nature of bulk DOM as a function of its fluorescent functional groups and has been used to distinguish and track water masses (e.g. Del Castillo et al., 1999; Boyd and Osburn, 2004; Guéguen et al., 2007). Construction of an EEM contour allows the detection of the position of maximum emission at maximum excitation, i.e. $(\mathrm{Ex} / \mathrm{Em})_{\max }$, and it is a simple, rapid and sensitive method for CDOM concentration and composition requiring a small volume of sample.

The $(\mathrm{Ex} / \mathrm{Em})_{\max }$ peaks in EEM contours have generally been associated with what have been termed humic-like fluorescence (defined as peaks A, C, and M) and protein-like florescence (defined as peaks B and T) (Coble, 1996). Protein-like peaks result from the fluorescence of the aromatic amino acids tyrosine and tryptophan either in their monomeric forms or, more likely, incorporated into reactive protein/peptides or more refractory humic-type materials (Determann et al., 1998; Mayer et al., 1999; Yamashita and Tanoue, 2003). Due to its ability to identify protein-like materials, EEM spectroscopy has been used studying water quality evaluation (Baker, 2001; Baker and Inverarity, 2004) and marine algal and bacteria dynamics (Determann et al., 1998). Furthermore, since both CDOM and chlorophyll strongly absorb blue light, it is essential to understand how changes in concentration and optical properties of CDOM can affect the interpretation of remote sensing data (Siegel et al., 2002; Magnuson et al., 2004).

Estuarine, coastal, and marsh ecosystems are hot spots of DOM cycling because their DOM composition is controlled by the relative abundance of many different DOM sources as well as the complex interactions of physical, photochemical and microbial processes. The highest concentrations of CDOM are always found in coastal margins and semi-enclosed seas, where direct sources of terrestrial DOM are present (e.g. Mayer et al., 1999; Del Castillo et al., 1999; Kowalczuk et al., 2003). The geographical extent of the terrestrially dominated regions varies seasonally, depending on the magnitude of freshwater inputs.

Zhejiang is one of the most developed provinces in China, and its adjacent coastal areas are greatly affected by the rapid increasing population and economic development. The terrestrial 
substances are transported to the seas by local rivers, and also probably by underground water discharge. At the same time, the Zhejiang coasts are surrounded by the sub-aqueous mud wedge originating from the Changjiang Estuary (Liu et al., 2007), which has been suggested in other regions to be a potential CDOM source to the overlying water (Clark et al., 2008; Tzortziou et al., 2008). Therefore, measurements of CDOM properties in different types of water samples along the Zhejiang coasts can help explain the varying effects of a series of controlling factors, such as human effects, terrestrial inputs, muddy salt marsh releases, and pelagic saltwater upwelling and intrusion, on the CDOM dynamics.

In this study, we present results of CDOM absorption and fluorescence in water samples from various environments along the Zhejiang coasts, in the inner shelf of East China Sea. Little is known about the optical quality, composition, and transportation of CDOM within this marsh-estuarine ecosystem. Our objectives are (1) to illustrate the distribution and variability of CDOM in water samples along the Zhejiang coasts, and (2) to understand the processes that contribute to the CDOM source and dynamics during the mixing process between fresh- and salt- waters.

\section{Study Area and Methods}

2.1 Study area

Muddy banks are widely distributed along the Zhejiang coastline. The seismic profiling and coring show that the sub-aqueous mud wedge extends from the Changjiang mouth southward off the Zhejiang and Fujian coasts into the Taiwan Strait (Liu et al., 2007). There are numerous small islands and semi-enclosed bays along the Zhejiang coasts, favoring the development of muddy tidal flats (Wang and Jin, 1983). Most of the muddy sediments come from the Changjiang, with a few sources from small local rivers (Liu et al., 2007). From north to south along the study areas (Fig. 1), there are four mountainous rivers flowing in, i.e. Jiaojiang, Oujiang, Feiyunjiang, and Aojiang, which rank the 3rd, 2nd, 7th, and 8th, respectively, in terms of the catchment area among all the rivers in Zhejiang (Liu G.Y., unpublished data, http://www.zjwater.gov.cn/pages/document/10/document_313.htm). The detailed information about the four rivers is shown in Table 1.

Due to the rapid economic development and population growth, enormous quantities of nutrients and other pollutants are transported from land to sea in Zhejiang (Hua et al., 2008), which might have largely resulted in the increasing number and scale of harmful algal bloom events in the adjacent sea 
(Zhou et al., 2008). In recent decades, to meet the demand of social and economic development, more and more intertidal flats have been reclaimed for arable land and aquatic farms. Rapid land use changes have occurred along the Zhejiang coasts, in which urban areas have increased dramatically (Ding et al., 2007).

\subsection{Sampling}

Twenty-eight surface water samples from rivers, muddy intertidal flats, sand shores, and bedrock coasts were collected along the Zhejiang coastline (Fig. 1). In the north part of the study area, the coastline is characterized by distribution of broad muddy intertidal flats that are bordered landwards by the man-made seawalls (generally against 20-50 year floods), and bedrock coasts, gravel and sand shores were only present around some coastal headlands. To the south, the proportion of the muddy coasts decreases and they only appear in some semi-enclosed bays. On the other hand, the bedrock coasts begin to dominate the coastline, so that few seawalls are necessary. At the stations where samples 20-24 were collected, the dotted-distributed muddy flats were generally tied to the coastal bedrocks with a narrow sand shore transition or absent. At the two southernmost stations for sample 25 and 26 (which were actually located in the Fujian Province), the seawater fronts directly to the coastal bedrocks without any transition of intertidal muddy, sand, or gravel shores. Meanwhile, the water color in the two samples changed from brown to blue, presumably related to the reduced resuspended muddy particulates and the inherent CDOM property change. Besides the above Zhejiang samples, three additional ones 29-31 were also collected from the Changjiang (near Xuliujing) for comparison (Fig. 1), and the detailed information about all samples can be found in Table 2.

At each station, water samples were collected and then stored in dark immediately in an ice-box. Then, the samples obtained on that day were filtered into HDPE bottles using a pre-combusted GF/F filter $\left(0.7 \mu \mathrm{m}\right.$ in pore-size, Whatman Inc.) and then frozen in dark under $-20^{\circ} \mathrm{C}$ condition and defrosted overnight before being analyzed (within 12 days). The above sample storage protocol is commonly used for CDOM studies (e.g. Yamashita and Tanoue, 2003; Burdige et al., 2004; Jiang et al., 2008), when sample sites are remote from laboratories.

\subsection{Measurements}

\subsubsection{CDOM absorption}

Measurements of CDOM absorption were performed using a UV-visible spectrophotometer (Model: TU1810DPC, Beijing Purkinje Inc.) with a 5-cm path-length quartz cuvette. Measurements 
120

121

122

123

124

125

126

127

128

130

131

132

133

134

135

136

137

138

139

140

141

142

were baseline-corrected using Milli-Q water and by running a new blank before each sample. Measurements covered the wavelength range of 300 to $800 \mathrm{~nm}(0.5-\mathrm{nm}$ interval). The data were corrected for scattering and baseline fluctuations by subtracting from each spectrum the value of absorption at $700 \mathrm{~nm}$ (Bricaud et al., 1981). The absorptions at $300 \mathrm{~nm}, a_{\mathrm{CDOM}}(300)$, were chosen as an index of CDOM abundance. The spectral slope $S_{\mathrm{CDOM}}(300-500)$ that determined the rate of the exponential decline of CDOM absorption with increasing wavelengths, was estimated after applying nonlinear exponential regression to $a(\lambda)$ measured in the wavelength range of $300-500 \mathrm{~nm} . R^{2}$ values of the nonlinear fits were in almost all cases higher than 0.99 .

\subsubsection{CDOM fluorescence}

CDOM fluorescence EEM contours were obtained with a Hitachi F-2500 spectrofluorometer similar to some previous studies (Coble et al., 1993; Mayer et al., 1999; Jiang et al., 2008), using a 1-cm quartz cell (Hitachi). Briefly, the excitation and emission bandwidths were both set at $5 \mathrm{~nm}$. The spectrofluorometer was set at a scan speed of $300 \mathrm{~nm} \mathrm{~min}^{-1}$, a PMT voltage of $700 \mathrm{~V}$, and an auto response time. If necessary, samples were diluted before being measured to make the absorption at 370 nm lower than 0.1 using the 5-cm path length cuvette; and under such condition both re-absorption and inner filter effects were minimized (Guéguen et al., 2007). EEMs were recorded by scanning emission wavelengths from 230 to $600 \mathrm{~nm}$ repeatedly (by $0.5-\mathrm{nm}$ intervals) at excitation wavelengths from 220 to $450 \mathrm{~nm}$ (by 5-nm increments). Final EEMs were interpolated (by 2.5-nm interval) and smoothed (by $5 \times 5$ moving average method) using the Surfer software (version 8, Golden Software Inc.) Daily-determined Milli-Q water was used as a blank and subtracted from sample spectra to remove Raman signals. Rayleigh scatter effects were removed by only including certain emission measurements shown in all EEM contours in this paper. The $(\mathrm{Ex} / \mathrm{Em})_{\max }$ positions and intensities of the four fluorescence peaks (i.e. $F(\mathrm{SR}), F(\mathrm{BT}), F(\mathrm{~A})$, and $F(\mathrm{C})$ ) were determined by examining the smoothed EEM contours. Fluorescence intensities are reported using the Raman Units $\left(\mathrm{nm}^{-1}\right)$ according to some previous studies (Nieke et al., 1997; Huguet et al., 2009).

Just in recent years, some studies (e.g. Spencer et al., 2007) suggested that freezing is not a suitable sample storage protocol for absorption and fluorescence measurements; and ideally, samples have to be stored in the cold $\left(4^{\circ} \mathrm{C}\right)$ and dark for less than $48 \mathrm{~h}$ to be representative of in situ conditions. To test the freeze/thaw procedure on the optical results of our samples, a water sample was collected from Huangpujiang $\left(31^{\circ} 01^{\prime} 02^{\prime \prime} \mathrm{N}, 121^{\circ} 28^{\prime} 39^{\prime \prime} \mathrm{E}\right.$; a river flowing through the city of Shanghai) and 
150

151

152

153

154

155

156

157

158

159

160

161

162

163

164

165

166

167

168

169

170

171

172

173

174

175

176

177

178

179

measured after using three storage protocols, i.e. stored in $4^{\circ} \mathrm{C}$ for less than $48 \mathrm{~h}$, stored in $4^{\circ} \mathrm{C}$ for 12 days, and stored in freezing $\left(-20^{\circ} \mathrm{C}\right)$ for 12 days. Similar to most of our samples, the Huangpujiang sample also suffered from a great anthropogenic influence (Yang et al., 2007). Our results show that although there are obvious modifications of measurements after 12 days (in freezing or in $4^{\circ} \mathrm{C}$ ) for the five quantitative indexes (i.e. $a_{\mathrm{CDOM}}(300), F(\mathrm{SR}), F(\mathrm{BT}), F(\mathrm{~A})$, and $F(\mathrm{C})$ ), the percent differences are all less than $15 \%$ (Table 3), much smaller than the variation ranges of the Zhejiang samples over one or even two orders of magnitude for the five indexes (mentioned later). For the two qualitative indexes of $S_{\mathrm{CDOM}}(300-500)$ and $F(\mathrm{~A}) / F(\mathrm{BT})$, the maximal differences among the nine measurements (three for each protocol) are $0.0009 \mathrm{~nm}^{-1}$ and $0.04 \mathrm{~nm}^{-1} / \mathrm{nm}^{-1}$, respectively, still much smaller than those Zhejiang samples $\left(0.0067 \mathrm{~nm}^{-1}\right.$ and $\left.3.03 \mathrm{~nm}^{-1} / \mathrm{nm}^{-1}\right)$. In terms of $(\mathrm{Ex} / \mathrm{Em})_{\max }$ positions for the four fluorescence peaks, no significant modification has been introduced by freezing (Table 3). Therefore, we believe that the main conclusions in this study should not have been changed by the measurement biases induced from the freeze/thaw procedure.

\subsubsection{Additional measurements}

Nutrients were determined using a Segmented Flow Analyzer (Model: San ${ }^{\text {plus }}$ System, SKALAR Inc.) (Grasshoff et al., 1999). DOC concentrations were determined by thermal catalysis at $680^{\circ} \mathrm{C}$ in a Shimadzu TOC-VCPN instrument, and samples were acidified to about $\mathrm{pH}=2$ with $85 \%$ phosphoric acid and then sparged for 10 min before being injected. Salinity and $\mathrm{pH}$ were measured directly by YSI 650MDS multi-parameter sonde. Estimation of suspended particulate matter (SPM) was based on 200-400 $\mathrm{ml}$ water samples filtered through pre-weighed $\mathrm{GF} / \mathrm{F}$ filters that were then dried at $50^{\circ} \mathrm{C}$ for 48 $\mathrm{h}$ and weighed again; the difference of filter weights with and without particulates, together with the volume of filtered water, was used to calculate the SPM values.

\section{Results}

\subsection{Nutrients and DOC}

Nutrients, DOC, and salinity data (shown in Fig. 2) were statistically analyzed by principal component analysis (PCA) (SPSS version 11.5, SPSS Inc.), which is a variable-reduction procedure that can be defined as a linear combination of optimally weighted variables. The optimal weights are created by the principle of least squares similar to the linear regression. In our case, PCA was done with data from the seven variables (i.e. salinity, five nutrients, and DOC) for the 28 cases (i.e. the 28 
180

181

182

183

184

185

186

187

188

189

190

191

192

193

194

195

196

197

198

199

200

201

202

Zhejiang samples). The 28 samples were then artificially classified into four types (Type A, B, C, and D) mainly according to the PCA results (Fig. 3).

The two samples 16 and 19 are categorized into Type A, with extremely high $\mathrm{NH}_{4}{ }^{+}$and near-zero $\mathrm{NO}_{3}^{-}$values (Fig. 2b and d); in addition, they show the highest DOC levels (Fig. 2f). During the field investigation, sample 16 was collected from a tidal pond on a higher muddy flat, which seemed to have not been refreshed by the upcoming tidal currents for several semidiurnal cycles. Sample 19 was collected in a ferry port in Aojiang that had been greatly polluted by municipal wastewater. The three samples 1, 27, and 28 are classified as Type B, which were all collected from local rivers and with salinity less than 0.3 . In the nutrient-salinity relationships, the two samples from Oujiang (27 and 28) show relatively higher $\mathrm{NO}_{3}{ }^{-}$and $\mathrm{NO}_{2}{ }^{-}$and lower $\mathrm{NH}_{4}{ }^{+}$and DOC concentrations (Fig. 2b-d, f). Most (19 out of 28$)$ of the samples $(2-15,17,18$, and 20-22) are Type $C$, because they were all collected from the muddy flats along the Zhejiang coasts. The last four samples (23-26), obtained in the southern part of the study area, are grouped into Type D since they show different fluorescence features (discussed later). Among the above four samples, two of them (25 and 26) were collected from bedrock coasts with blue water color, partly because they contained lower SPM values (Table 2). The $\mathrm{NO}_{2}{ }^{-}$and $\mathrm{PO}_{4}{ }^{3-}$ concentrations for the four samples in Type D are relatively higher than others, whereas their DOC values are somewhat lower (Fig. 2c, e, and f). The negative relationships between concentration and salinity (Fig. 2a, b, and f) suggest that distributions of $\mathrm{SiO}_{3}{ }^{2-}, \mathrm{NO}_{3}{ }^{-}$, and DOC in the Zhejiang samples were in part controlled by the mixing process between fresh- and salt- waters.

\subsection{CDOM absorption}

The CDOM abundance index $a_{\mathrm{CDOM}}(300)$ is highly linear correlated with DOC (Fig. 4), suggesting CDOM signatures can be used to represent DOC concentration in the study area. The positive intercept in the $y$-axis $\left(48.1 \mu \mathrm{M}\right.$ of DOC when $a_{\mathrm{CDOM}}(300)$ equals zero) implies the presence of DOC compounds unrelated to the CDOM dynamics.

The CDOM spectral slope, $S_{\mathrm{CDOM}}(300-500)$, is believed to reflect the CDOM composition change of humic to fulvic or high-molecular-weight to low-molecular-weight proportions (Carder et al., 1989; Twardowski and Donaghay, 2002). In the present study, the $S_{\mathrm{CDOM}}(300-500)$ results range between 0.0082 to $0.0149 \mathrm{~nm}^{-1}$, in which sample 16 and 13 contribute to the highest and lowest values, respectively. In previous studies, Kowalczuk et al. (2005) found the increasing spectral slopes with decreasing absorptions in the Baltic Sea. Green and Blough (1994) also observed that the lowest 
spectral slopes and highest absorptions always correspond to inland and coastal samples, while the offshore blue waters generally have the opposite values. In contrast with the two studies, the two parameters among the 28 Zhejiang samples are slightly positively correlated (the solid line in Fig. 5). However, when only the two groups of samples in Type C and Type D are compared, a slightly negative regression, rather than positive, between $S_{\mathrm{CDOM}}(300-500)$ and $a_{\mathrm{CDOM}}(300)$ occurs (the dotted line in Fig. 5).

\subsection{CDOM fluorescence}

Fluorescence EEM contours we obtained (Fig. 6) contain a number of distinct peaks that are generally ascribed to either humic-like or protein-like fluorescence. Coble (1996) reported the two protein-like fluorescence peaks: peak $B$ at $(E x / E m)_{\max }=275 / 310 \mathrm{~nm}$ due to tyrosine, and peak $\mathrm{T}$ at $(E x / E m)_{\max }=275 / 340 \mathrm{~nm}$ due to tryptophan. Later, Mayer et al. (1999) found the additional two protein-like fluorescence peaks at lower excitation wavelengths $\left(\operatorname{Ex}_{\max }=220-230 \mathrm{~nm}\right)$ and similar emission wavelengths, as had not been found by Coble (1996) because the author did not use excitation wavelengths lower than $260 \mathrm{~nm}$. Burdige et al. (2004) named these additional peaks as peak S for tyrosine and peak R for tryptophan. In this study, similar to Burdige et al. (2004), we also quantify protein-like fluorescence simply in terms of high and low excitation wavelengths, i.e. combined peaks of BT and SR, without further discrimination of the two amino acid sources.

In samples belonging to Type A, B, and C (Fig. 6a-f), in addition to the two protein-like peaks (i.e. SR and BT), the EEM contours show clearly a third peak that has been linked to the humic-like peak A (Coble, 1996). In the other four samples of Type D (Fig. 6g and h), the peak A becomes the only distinct one in the EEM contours. In all the 28 EEM contours, the humic-like peaks $\mathrm{C}$ and M (Coble, 1996; Parlanti, et al., 2000) generally only appear as shoulders on the tail of the adjacent prominent peaks (Fig. 6), and it is not easy to precisely distinguish the (Ex/Em) $)_{\max }$ positions of the two peaks. Hence, in this study we only quantify the heights of peak C at the fixed Ex/Em wavelength of 350/450 nm recommended by Coble (1996).

The EEM contour of sample 16 (Fig. 6a) shows much higher fluorescence values than the other 27 samples throughout the spectrum; hence this sample is removed in the following correlation calculations. Table 4 shows that any two of the four EEM peak intensities (i.e. $F(\mathrm{SR}), F(\mathrm{BT}), F(\mathrm{~A})$, and $F(C))$ among the remaining 27 samples are significantly correlated; in addition, the four peak values are also highly correlated with DOC or $a_{\mathrm{CDOM}}(300)$. 
PCA is employed for the second time on the 13 variables (i.e. the seven variables in the first PCA

241

242

243

in Fig. 3 plus $a_{\mathrm{CDOM}}(300), S_{\mathrm{CDOM}}(300-500)$, and the four fluorescence EEM peak heights) for the 28 samples. Compared to those in Fig. 3, the relative positions for the 28 samples in the new PCA plot are not largely changed after introducing the six new parameters (plot not shown); and the previous classification of the four types for the 28 samples is still valid.

\section{Discussion \\ 4.1 Comparison with the Changjiang freshwater}

Three Changjiang water samples (29-31, shown in Fig. 1) were collected in March and April 2008 with salinity all less than 0.3 , and their EEM contours are shown in Fig. 7 . In summer under the prevailing southeast monsoon, the northward Taiwan Warm Current intensifies, and correspondingly the southward Zhejiang-Fujian Coastal Current weakens (Beardsley et al., 1985; Lee and Chao, 2003). Hence during the investigation period of July 2007, the influence of the Changjiang Diluted Water on Zhejiang coastal seawater is believed to be minimized. As has been mentioned, the EEM contours of the 28 Zhejiang samples can be separated into two categories. Samples 1-22 and 27-28 (Type A, B, and $\mathrm{C}$; Fig. 6a-f) belong to the first category, whose EEM contours show distinct SR and BT peaks with heights comparable to or even higher than peak A. However, in the second category, EEM contours of samples 23-26 (Type D, Fig. 6g and h) show SR or BT signatures generally only as the shoulders of peak A. Concerning the three Changjiang freshwater samples (Fig. 7), their EEM contours seem to lie between those two categories of Zhejiang samples, because the fluorescence ratio of peak A to peak BT, $F(\mathrm{~A}) / \hat{F}(\mathrm{BT})$, for the three Changjiang waters ranges between 2.0-2.2, comparing to 0.4-1.6 for Zhejiang samples in the first category and 2.4-3.4 in the second.

Relationships between salinity and the four EEM peak heights (i.e. $F(\mathrm{SR}), F(\mathrm{BT}), F(\mathrm{~A})$, and $F(\mathrm{C})$ )

for all the 31 samples (the 28 Zhejiang samples plus the three Changjiang samples) are shown in Fig. 8. The two samples from Oujiang (sample 27 and 28) and the three ones from Changjiang (sample 29-31) are always clustered together at the bottom left area of the diagrams. If the five data points and that of sample 16 are removed, negative linear correlations can generally be established (Fig. 8). Different from Jiaojiang, Feiyunjiang, and Aojiang (sample 1, 18, and 19), the five river samples from Oujiang and Changjiang with much higher freshwater runoff (Table 1) provide fluorescence values much lower than those the calculated regression lines suggest (Fig. 8), implying Oujiang is not a main source of 
fluorophores measured in other Zhejiang samples. The above results also suggest that the concentrations of fluorescent compounds in large rivers (e.g. Changiang and Oujiang) may be determined by different mechanisms from those of smaller ones (e.g. Jiaojiang, Feiyunjiang, and Aojiang).

\subsection{Identification of the freshwater end-member}

According to the fluorescence-salinity relationships (Fig. 8), the fluorophores from Oujiang should not be the main origin of CDOM measured in other samples. Also, due to the much lower freshwater outputs (Table 1), CDOM compounds in most Zhejiang samples unlikely originated from Jiaojiang, Feiyunjiang, and Aojiang. In fact, from the salinity results in the 28 samples along the Zhejiang coasts (Fig. 9) we can hardly find their specific variations in response to the freshwater outputs from nearby local rivers. It is consequently important to determine the freshwater source, which is also closely associated with the origins of nutrients, DOC, and CDOM molecules since their concentrations are primarily or partly controlled by salinity in most samples (Figs. 2, 4, and 8).

We notice that a surprisingly low salinity 1.9 is shown in sample 16 , which was collected in a high-elevation tidal pond having not been recharged by upcoming tidal currents for several semidiurnal cycles. Firstly, this sample unlikely originated from the adjacent local rivers because (1) there are no small rivers nearby, and (2) its salinity is much lower than those adjacent samples $(14,15,17$, and 18$)$ that are closer to Oujiang and Feiyunjiang (Fig. 1). Secondly, sample 16 was not influenced by rainwater because (1) there was no rain record during the investigation days, and (2) its nutrient results (Fig. 2) are dramatically different from those rainwater samples obtained in the nearby regions (Zhang et al., 2005). In fact, the first author (Gao L.) had also collected a rainwater sample in the Changiiang Estuary in August 2005, whose nutrient concentrations were $4.5 \mu \mathrm{M}$ for $\mathrm{SiO}_{3}{ }^{2-}, 1.4 \mu \mathrm{M}$ for $\mathrm{NO}_{2}^{-}, 113.4$ $\mu \mathrm{M}$ for $\mathrm{NH}_{4}{ }^{+}, 95.0 \mu \mathrm{M}$ for $\mathrm{NO}_{3}^{-}$, and $0.5 \mu \mathrm{M}$ for $\mathrm{PO}_{4}{ }^{3-}$ (unpublished data). Compared to sample 16 , the rainwater contains much lower $\mathrm{SiO}_{3}{ }^{2-}(4.5$ vs. $223.7 \mu \mathrm{M})$ and $\mathrm{NH}_{4}{ }^{+}(113.4$ vs. $1049 \mu \mathrm{M})$, and higher $\mathrm{NO}_{3}^{-}(95.0$ vs. $2.0 \mu \mathrm{M})$ concentrations.

Submarine groundwater discharge (SGD) in coastal areas was neglected scientifically for many years because of the difficulty in its quantification. In recent years, according to radiochemical and stable isotope measurements, more and more studies showed that SGD outputs are chemically and ecologically important to coastal waters. For example, Dulaiova et al. (2006) found the SGD runoff can represent about $20 \%$ of the river flow during low-flow periods and $4 \%$ during high-flow conditions in 
300

301

302

303

304

305

306

307

308

309

310

311

312

313

314

315

316

317

318

319

320

321

the estuarine region of the Chao Phraya River (discharging into the Gulf of Thailand). Paytan et al. (2006) estimated that nitrogen inputs by SGD range between 3 to $800 \mathrm{mmol} \mathrm{h}^{-1}$ per meter of shoreline in the coral reef ecosystems around the world. Other studies also showed that terrestrially derived inputs from SGD play an important role in the discharge of nutrients and other compounds, especially in areas where the terrestrial outputs by rivers are not significant (Burnett et al., 2003; Charette and Buesseler, 2004; Hays and Ullman, 2007).

During the investigation for the present study, 11 sediment cores (with lengths of about $1 \mathrm{~m}$ ) were also obtained by manual digging at low tides in different muddy intertidal flats. During the digging process, rapid porewater advection filling into the excavation hole was always observed, which directly verified the considerable underground water discharge in the study area.

Therefore, we may consider that the sample 16 is actually from SGD outputs. This sample had hardly been affected by the recycled seawater due to its very low salinity, although it might have been greatly modified by inherent chemical processes. The tidal pond where sample 16 was collected is in fact acting as the 'monitoring well', by which SGD samples in coastal areas were collected in many previous studies (Dulaiova et al., 2006; Hays and Ullman, 2007; McCoy et al., 2007). The salinity variation among the Zhejiang samples (Fig. 9) presumably largely reflects the varying magnitude of the SGD fluxes from local permeable sediments. Further, the variation among the three samples $2-4$ (with salinity ranging from 25.6 to 33.7 ), which were collected at the same station and on the same day but at different tidal phases, presumably reveals the reciprocating motion of the subterranean freshwater-saltwater interface within a tidal cycle (Robinson et al., 2007).

In the DOC-salinity relationship (Fig. 2f), the value of sample 16 is in the same order of magnitude when compared with the freshwater end-member value suggested by the regression line. In the $F(\mathrm{~A})$-salinity and $F(\mathrm{C})$-salinity diagrams (Fig. $8 \mathrm{c}$ and d), similar distributions of data points are also observed. The above results imply that the SGD might provide a part of DOC (Fig. 2f), CDOM absorbents (deduced from Figs. $2 \mathrm{f}$ and 4) and humic-like fluorophores (Fig. $8 \mathrm{c}$ and d) measured in the most Zhejiang samples, whose concentrations decrease near-conservatively during the freshwater-saltwater mixing process. When, however, considering the protein-like peaks SR and BT, their levels in sample 16 are unusually high (Fig. $8 a$ and b, note the breaks in the $y$-axes). If the sample 16 was considered as the freshwater end-member, the protein-like fluorophores would have been largely removed/assimilated at intermediate salinities, presumably by photobleaching, adsorption to 
particles, and/or flocculation (Miller, 1999; Abril et al., 2002; Stedmon and Markager, 2003). Another possibility is that $F(\mathrm{SR})$ or $F(\mathrm{BT})$ values in sample 16 had been greatly elevated by in situ processes. The various processes changing the fluorescence values of the two protein-like peaks are discussed in the next section.

\subsection{The high protein-like fluorescence peaks}

The two protein-like peaks can be observed in most EEM contours of samples in the present study, consistent with other Chinese coastline surface seawaters (Hong et al., 2005; Jiang et al., 2008). The high contribution of protein-like materials to the fluorescence EEM contours was also found in a large number of coastal oceans worldwide (e.g. Mayer et al., 1999; Kowalczuk et al,, 2003; Burdige et al., 2004). All of the above studies highlight the importance of elucidating the origin of these protein-like fluorophores.

Baker et al. (2001) studied the EEM contours in the sewage-impacted waters and found that these samples always displayed high protein-like fluorescence peaks; they concluded that the sewage (even after treatment) and other agricultural waste and industrial discharges can behave as a high-protein source to adjacent coastal seawaters. Similar conclusion was also reached by Hudson et al. (2007). Our study area is surrounded by two big cities of Wenzhou and Taizhou (shown in Fig. 1), which are under the influence of heavy urbanization and industrialization. Also, the sampling stations were always close to the aquatic farms for fisheries and agriculture. Therefore, it is reasonable that the distinct protein-like peaks in most samples are caused at least partly by the land-based protein pollution.

The contribution of anthropogenic activities to the protein-like peaks can be validated by the results of sample 19, which was collected from a ferry port in Aojiang. This sample contains the second, third, and second highest SR and BT fluorescence heights and $\mathrm{NH}_{4}^{+}$concentration, respectively (Figs. 2d, $8 \mathrm{a}$ and $\mathrm{b}$ ), and it also exhibits near-zero $\mathrm{NO}_{3}{ }^{-}$level (Fig. $\left.2 \mathrm{~b}\right)$.

It is still possible that some protein-like fluorophores originate from inherent aquatic processes, such as primary productivity and respiration consumption by phytoplankton, and degradation of bacteria. The co-occurrences of the high $\mathrm{NH}_{4}{ }^{+}$concentration and the two protein-like peaks in sample 16 strongly suggest the biological degradation processes in the field. Also, although the near-zero $\mathrm{NO}_{3}{ }^{-}$ concentration in sample 16 is similar to that in Aojiang (sample 19), it is obviously lower than those in other local rivers (sample 1, 18, 27, and 28; Fig. 2b) and most of the rivers in other regions suffering from a great influence of human activities (e.g. the Huangpujiang river, see Yang et al., 2007). Several 
360

361

362

363

364

365

366

367

368

369

370

371

372

373

374

375

376

377

378

379

380

381

382

studies have observed high benthic denitrification rates in the Changjiang Estuary intertidal flats, which remarkably decreased the $\mathrm{NO}_{3}{ }^{-}$concentrations in the overlying water (Wang et al., 2007; Gao et al., 2008). Therefore, sample 16 might have also been experiencing, until being sampled, considerable denitrification that not only reduced $\mathrm{NO}_{3}{ }^{-}$levels but also might have altered the concentrations and properties of DOC and CDOM substances, including the protein-like fluorophores.

\section{Conclusions}

The Zhejiang coasts are a representative area in which great physical, chemical, geological and biological processes, as well as human activities all exert their complex influences on the CDOM distribution and biogeochemistry. In the present study, we classify the 28 surface water samples obtained along the Zhejiang coasts into four types, according to their nutrient, DOC, and optical measurements. The two samples in Type A (16 and 19) are highly polluted and/or greatly in situ modified, because they contain extremely high $\mathrm{NH}_{4}{ }^{+}$and protein-like fluorescence values as well as near-zero $\mathrm{NO}_{3}{ }^{-}$concentrations. The three samples in Type $\mathrm{B}(1,27$, and 28$)$ were all collected from local rivers; in which the two samples from Oujiang (27 and 28) show similar properties with the Changjiang waters, in terms of the relationships between salinity and fluorescence values of the four EEM peaks. Most of the samples (19 out of 28) belong to Type C, since they were generally obtained from the northern study areas that were under the influence of the 'mud belt' depositing on the inner shelf of East China Sea. Concerning the fluorescence EEM contours, the two protein-like peaks (SR and BT) in samples of Type A, B, and C can be easily discerned with magnitudes comparable to or even higher than those of the humic-like peak A. However, in the EEM contours of Type D samples (23-26), the protein-like signals only exhibit as shoulders of the dominant peak A. The underground water discharge, rather than local river inputs, might have actually provided the most CDOM substances measured in the Zhejiang samples. The protein-like fluorophores in samples of Type A, B, and $\mathrm{C}$ should have multiple sources, such as terrestrial inputs, land-based pollution, and local biological activities.

\section{Acknowledgements}

The authors thank Profs. Cong-Xian Li and Shou-Ye Yang, Drs. Guo-Dong Xu, Cheng-Xing Sun, 
389 and Guo-Sen Zhang for their great help during field and laboratory work. The two anonymous

390 reviewers and Prof. Roberts B. Spies are appreciated for giving the detailed comments, which have

391 greatly improved the manuscript. This work was jointly funded by Natural Science Foundation of

392 China (Nos. 40876021 and 40672085), Ministry of Education of China (No. NCET-07-0619), and

393 Science and Technology Commission of Shanghai Municipality (Nos. 07R214142 and 07DZ14003). 
References:

Abril, G., Nogueira, M., Etcheber, H., Cabeçadas, G., Lemaire, E., Brogueira, M.J., 2002. Behaviour of organic carbon in nine contrasting European estuaries. Estuarine, Coastal and Shelf Science 54, $241-262$.

Baker, A., 2001. Fluorescence excitation-emission matrix characterization of some sewage-impacted rivers. Environmental Science and Technology 35, 948-953.

Baker, A., Inverarity, R., 2004. Protein-like fluorescence intensity as a possible tool for determining river water quality. Hydrological Progresses 18, 2927-2945.

Beardsley, R.C., Limeburner, R., Yu, H., Cannon, G.A., 1985. Discharge of the Changjiang (Yangtze River) into the East China Sea. Continental Shelf Research 4, 57-76.

Boyd, T.J., Osburn, C.L., 2004. Changes in CDOM fluorescence from allochthonous and autochthonous sources during tidal mixing and bacterial degradation in two coastal estuaries. Marine Chemistry 89, 189-210.

Bricaud, A., Morel, A., Prieur, L., 1981. Absorption by dissolved organic matter of the sea (yellow substance) in the UV and visible domains. Limnology and Oceanography 26, 43-53.

Burdige, D.J., Kline, S.W., Chen, W., 2004. Fluorescent dissolved organic matter in marine sediment pore waters. Marine Chemistry 89, 289-311.

Burnett, W.C., Bokuniewicz, H., Huettel, M., Moore, W.S., Taniguchi, M., 2003. Groundwater and pore water inputs to the coastal zone. Biogeochemistry 66, 3-33.

Carder, K.L., Steward, R.G., Harvey, G.R., Ortner, P.B., 1989. Marine humic and fulvic acids: Their effects on remote sensing of ocean chlorophyll. Limnology and Oceanography 34, 68-81.

Charette, M.A., Buesseler, K.O., 2004. Submarine groundwater discharge of nutrients and copper to an urban subestuary of Chesapeake Bay (Elizabeth River). Limnology and Oceanography 49, $376-385$.

Clark, C.D., Litz, L.P., Grant, S.B., 2008. Salt marshes as a source of chromophoric dissolved organic matter (CDOM) to Southern California coastal waters. Limnology and Oceanography 53, 1923-1933.

Coble, P.G., 1996. Characterization of marine and terrestrial DOM in seawater using excitation-emission matrix spectroscopy. Marine Chemistry 51, 325-346.

Coble, P.G., 2007. Marine optical biogeochemistry: the chemistry of ocean color. Chemical Reviews 
107, 402-418.

Coble, P.G., Green, S.A., Blough, N.V., Gagosian, R.B., 1990. Characterization of dissolved organic matter in the Black Sea by fluorescence spectroscopy. Nature 348, 432-435.

Coble, P.G., Schultz, C.A., Mopper, K., 1993. Fluorescence contouring analysis of DOC Intercalibration Experiment samples: a comparison of techniques. Marine Chemistry 41, 173-178.

Del Castillo, C.E., Coble, P.G., Morell, J.M., López, J.M., Corredor, J.E., 1999. Analysis of the optical properties of the Orinoco River plume by absorption and fluorescence spectroscopy. Marine Chemistry 66, 35-51.

Determann, S., Lobbes, J.M., Reuter, R., Rullkötter, J., 1998. Ultraviolet fluorescence excitation and emission spectroscopy of marine algae and bacteria. Marine Chemistry 62, 137-156.

Ding, H., Wang, R.C., Wu, J.P., Zhou, B., Shi, Z., Ding, L.X., 2007. Quantifying land use change in Zhejiang coastal region, China using multi-temporal landsat TM/ETM + Images. Pedosphere 17, $712-720$.

Dulaiova, H., Burnett, W.C., Wattayakorn, G., Sojisuporn, P., 2006. Are groundwater inputs into river-dominanted areas important? The Chao Phraya River - Gulf of Thailand. Limnology and Oceanography 51, 2232-2247.

Gao, L., Li, D., Wang, Y., Yu, L., Kong, D., Li, M., Li, Y., Fang, T., 2008. Benthic nutrient fluxes in the intertidal flat within the Changjiang (Yangtze River) Estuary. Chinese Journal of Geochemistry 27, $58-71$.

Grasshoff, K., Kremling, K., Ehrhardt, M., 1999. Methods of Seawater Analysis (3rd edition). Wiley-VCH, Weinheim. 600 pp.

Green, S.A., Blough, N.V., 1994. Optical absorption and fluorescence properties of chromophoric dissolved organic matter in natural waters. Limnology and Oceanography 39, 1903-1916.

Guéguen, C., Guo, L.D., Yamamoto-Kawai, M., Tanaka, N., 2007. Colored dissolved organic matter dynamics across the shelf-basin interface in the western Arctic Ocean. Journal of Geophysical Research 112, C05038, doi: 10.1029/2006JC003584.

Hays, R.L., Ullman, W.J., 2007. Direct determination of total and fresh groundwater discharge and nutrient loads from a sandy beachface at low tide (Cape Henlopen, Delaware). Limnology and Oceanography 52, 240-247.

Hong, H., Wu, J., Shang, S., Hu, C., 2005. Absorption and fluorescence of chromophoric dissolved 
organic matter in the Pearl River Estuary, South China. Marine Chemistry 97, 78-89.

Hua, L., Wu, W.X., Liu, Y.X., Tientchen, C.M., Chen, Y.X., 2008. Heavy metals and PAHs in sewage sludge from twelve wastewater treatment plants in Zhejiang Province. Biomedical and Environmental Sciences 21, 345-352.

Hudson, N., Baker, A., Reynolds, D., 2007. Fluorescence analysis of dissolved organic matter in natural, waste and polluted wasters - a review. River Research and Applications 23, 631-649.

Huguet, A., Vacher, L., Relexans, S., Saubusse, S., Froidefond, J.M., Parlanti, E., 2009. Properties of fluorescent dissolved organic matter in the Gironde Estuary. Organic Geochemistry 40, 706-719.

Jiang, F., Lee, F.S.C., Wang, X., Dai, D., 2008. The application of Excitation/Emission Matrix spectroscopy combined with multivariate analysis for the characterization and source identification of dissolved organic matter in seawater of Bohai Sea, China. Marine Chemistry 110, 109-119.

Kowalczuk, P., Cooper, W.J., Whitehead, R.F., Durako, M.J., Sheldon, W., 2003. Characterization of CDOM in an organic-rich river and surrounding coastal ocean in the South Atlantic Bight. Aquatic Sciences 65, 384-401.

Kowalczuk, P., Stoń-Egiert, J., Cooper, W.J., Whitehead, R.F., Durako, M.J., 2005. Characterization of chromophoric dissolved organic matter (CDOM) in the Baltic Sea by excitation emission matrix fluorescence spectroscopy. Marine Chemistry 96, 273-292.

Lee, H.J., Chao, S.Y., 2003. A climatological description of circulation in and around the East China Sea. Deep-Sea Research II 50, 1065-1084.

Liu, J.P., Xu, K.H., Li, A.C., Milliman, J.D., Velozzi, D.M., Xiao, S.B., Yang, Z.S., 2007. Flux and fate of Yangtze River sediment delivered to the East China Sea. Geomorphology 85, 208-224.

Magnuson, A., Harding Jr., L.W., Mallonee, M.E., Adolf, J.E., 2004. Bio-optical model for Chesapeake Bay and the Middle Atlantic Bight. Estuarine, Coastal and Shelf Science 61, 403-424.

Mayer, L.M., Schick, L.L., Loder III, T.C., 1999. Dissolved protein fluorescence in two Marine estuaries. Marine Chemistry 64, 171-179.

McCoy, C.A., Corbett, D.R., McKee, B.A., Top, Z., 2007. An evaluation of submarine groundwater discharge along the continental shelf of Louisiana using a multiple tracer approach. Journal of Geophysical Research 112, C03013, doi: 10.1029/2006JC003505.

Miller, A.E.J., 1999. Seasonal investigations of dissolved organic carbon dynamics in the Tamar 
Estuary, U.K. Estuarine, Coastal and Shelf Science 49, 891-908.

Mopper, K., Schultz, C.A., 1993. Fluorescence as a possible tool for studying the nature and water column distribution of DOC components. Marine Chemistry 41, 229-238.

Nieke, B., Reuter, R., Heuermann, R., Wang, H., Babin, M., Therriault, J.C., 1997. Light absorption and fluorescence properties of chromophoric dissolved organic matter (CDOM), in the St. Lawrence Estuary (Case 2 waters). Continental Shelf Research 17, 235-252.

Parlanti, E., Wörz, K., Geoffroy, L., Lamotte, M., 2000. Dissolved organic matter fluorescence spectroscopy as a tool to estimate biological activity in a coastal zone submitted to anthropogenic inputs. Organic Geochemistry 31, 1765-1781.

Paytan, A., Shellenbarger, G.G., Street, J.H., Gonneea, M.E., Davis, K., Young, M.B., Moore, W.S., 2006. Submarine groundwater discharge: An important source of new inorganic nitrogen to coral reef ecosystems. Limnology and Oceanography 51, 343-348.

Robinson, C., Gibbes, B., Carey, H., Li, L., 2007. Salt-freshwater dynamics in a subterranean estuary over a spring-neap tidal cycle. Journal of Geophysical Research 112, C09007, doi: 10.1029/2006JC003888.

Siegel, D.A., Maritorena, S., Nelson, N.B., Hansell, D.A., Lorenzi-Kayser, M., 2002. Global distribution and dynamics of colored dissolved and detrital organic materials. Journal of Geophysical Research 107, C12, 3228, doi: 10.1029/2001JC000965.

Spencer, R.G.M., Bolton, L., Baker, A., 2007. Freeze/thaw and pH effects on freshwater dissolved organic matter fluorescence and absorbance properties from a number of UK locations. Water Research 41, 2941-2950.

Stedmon, C.A., Markager, S., 2003. Behaviour of the optical properties of coloured dissolved organic matter under conservative mixing. Estuarine, Coastal and Shelf Science 57, 973-979.

Sun, Y., Huang, W.S., 1984. The siltation process and silt sources of the Zhejiang coast. Donghai Marine Science 2(4), 34-42 (in Chinese with English Abstr.).

Twardowski, M.S., Donaghay, P.L., 2002. Photobleaching of aquatic dissolved materials: Absorption removal, spectral alteration, and their interrelationship. Journal of Geophysical Research 107, C8, 3091, doi: 10.1029/1999JC000281.

Tzortziou, M., Neale, P.J., Osburn, C.L., Megonigal, J.P., Maie, N., Jaffé, R., 2008. Tidal marshes as a source of optically and chemically distinctive colored dissolved organic matter in the Chesapeake 
Bay. Limnology and Oceanography 53, 148-159.

Wang, B.C., Jin, Q.X., 1983. An approach to evolution of mud coast of Wenzhou region in Zhejiang Province. Journal of East China Normal University (Natural Science Edition) 4, 75-86 (in Chinese with English Abstr.).

Wang, D., Chen, Z., Wang, J., Xu, S., Yang, H., Chen, H., Yang, L., Hu, L., 2007. Summer-time denitrification and nitrous oxide exchange in the intertidal zone of the Yangtze Estuary. Estuarine, Coastal and Shelf Science 73, 43-53.

Yamashita, Y., Tanoue, E., 2003. Chemical characterization of protein-like fluorophores in DOM in relation to aromatic amino acids. Marine Chemistry $82,255-271$.

Yang, H.J., Shen, Z.M., Zhang, J.P., Wang, W.H., 2007. Water quality characteristics along the course of the Huangpu River (China). Journal of Environmental Sciences 19, 1193-1198.

Zhang, J., Zhang, G.S., Liu, S.M., 2005. Dissolved silicate in coastal marine rainwaters: Comparison between the Yellow Sea and the East China Sea on the impact and potential link with primary production. Journal of Geophysical Research 110, D16304, doi: 10.1029/2004JD005411.

Zhou, M.J., Shen, Z.L., Yu, R.C., 2008. Responses of a coastal phytoplankton community to increased nutrient input from the Changjiang (Yangtze) River. Continental Shelf Research 28, 1483-1489. 
Table 1. Characteristics of the four local rivers in the study area

\begin{tabular}{ccccc}
\hline River & $\begin{array}{c}\text { Water Flux } \\
\left(10^{9} \mathrm{~m}^{3} \mathrm{yr}^{-1}\right)\end{array}$ & $\begin{array}{c}\text { Sediment Flux } \\
\left(10^{6} \mathrm{t} \mathrm{yr}^{-1}\right)\end{array}$ & $\begin{array}{c}\text { Length } \\
(\mathrm{km})\end{array}$ & $\begin{array}{c}\text { Catchment Area } \\
\left(10^{3} \mathrm{~km}^{2}\right)\end{array}$ \\
\hline Jiaojiang & $3.9^{\mathrm{a}}$ & $0.8^{\mathrm{a}}$ & $209^{\mathrm{b}}$ & $6.6^{\mathrm{b}}$ \\
Oujiang & $16.7^{\mathrm{a}}$ & $2.2^{\mathrm{a}}$ & $384^{\mathrm{b}}$ & $18.1^{\mathrm{b}}$ \\
Feiyunjiang & $2.4^{\mathrm{a}}$ & $0.4^{\mathrm{a}}$ & $193^{\mathrm{b}}$ & $3.7^{\mathrm{b}}$ \\
Aojiang & $0.5^{\mathrm{a}}$ & $0.08^{\mathrm{a}}$ & $81^{\mathrm{b}}$ & $1.5^{\mathrm{b}}$ \\
\hline
\end{tabular}

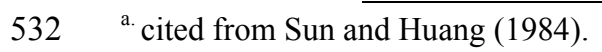

533 b. cited from Liu G.Y., unpublished data.

534 
536 Table 2. Characteristics of the 31 surface samples collected along the Zhejiang coasts (in 2007) as well as in the Changjiang river (in 2008)

\begin{tabular}{|c|c|c|c|c|c|c|c|}
\hline Sample \# & $\begin{array}{c}\text { Sampling } \\
\text { Date }\end{array}$ & Lat $(\mathrm{N})$ \& Long $(\mathrm{E})$ & Salinity & $\mathrm{pH}$ & $\begin{array}{c}\text { SPM } \\
\left(\mathrm{mg} \mathrm{L}^{-1}\right)\end{array}$ & $\begin{array}{l}\text { DOC } \\
(\mu \mathrm{M})\end{array}$ & $\begin{array}{c}a_{\mathrm{CDOM}}(300) \\
\left(\mathrm{m}^{-1}\right)\end{array}$ \\
\hline 1 & Jul-14 & $28^{\circ} 41^{\prime} 12^{\prime \prime}, 121^{\circ} 25^{\prime} 44^{\prime \prime}$ & 0.13 & 7.88 & 520 & 234.3 & 15.43 \\
\hline 2 & Jul-15 & $28^{\circ} 32^{\prime} 27^{\prime \prime}, 121^{\circ} 33^{\prime} 29^{\prime \prime}$ & 25.55 & 7.58 & 455 & 101.0 & 3.27 \\
\hline 3 & Jul-15 & $28^{\circ} 32^{\prime} 27^{\prime \prime}, 121^{\circ} 33^{\prime} 29^{\prime \prime}$ & 33.68 & 7.97 & 305 & 176.9 & 7.23 \\
\hline 4 & Jul-15 & $28^{\circ} 32^{\prime} 27^{\prime \prime}, 121^{\circ} 33^{\prime} 29^{\prime \prime}$ & 33.40 & 7.75 & 495 & 162.0 & 5.48 \\
\hline 5 & Jul-16 & $28^{\circ} 17^{\prime} 54^{\prime \prime}, 121^{\circ} 34^{\prime} 40^{\prime \prime}$ & 31.24 & 7.88 & 360 & 95.3 & 2.03 \\
\hline 6 & Jul-16 & $28^{\circ} 18^{\prime} 34^{\prime \prime}, 121^{\circ} 33^{\prime} 49^{\prime \prime}$ & 22.51 & 7.57 & 245 & 85.1 & 2.21 \\
\hline 7 & Jul-16 & $28^{\circ} 19^{\prime} 23^{\prime \prime}, 121^{\circ} 32^{\prime} 00^{\prime \prime}$ & 33.52 & 7.77 & 495 & 114.5 & 2.44 \\
\hline 8 & Jul-17 & $28^{\circ} 12^{\prime} 48^{\prime \prime}, 121^{\circ} 23^{\prime} 53^{\prime \prime}$ & 32.13 & 8.06 & 350 & 118.5 & 4.10 \\
\hline 9 & Jul-17 & $28^{\circ} 11^{\prime} 38^{\prime \prime}, 121^{\circ} 22^{\prime} 09^{\prime \prime}$ & 32.17 & 7.89 & 118 & 101.4 & 3.13 \\
\hline 10 & Jul-17 & $28^{\circ} 10^{\prime} 14^{\prime \prime}, 121^{\circ} 19^{\prime} 25^{\prime \prime}$ & 30.19 & 8.04 & & 105.3 & 4.01 \\
\hline 11 & Jul-18 & $28^{\circ} 21^{\prime} 10^{\prime \prime}, 121^{\circ} 10^{\prime} 21^{\prime \prime}$ & 21.17 & 7.81 & 420 & 132.9 & 6.77 \\
\hline 12 & Jul-18 & $28^{\circ} 16^{\prime} 48^{\prime \prime}, 121^{\circ} 06^{\prime} 33^{\prime \prime}$ & 26.09 & 7. & 340 & 135.4 & 5.11 \\
\hline 13 & Jul-18 & $28^{\circ} 07^{\prime} 28^{\prime \prime}, 121^{\circ} 02^{\prime} 30^{\prime \prime}$ & 27.98 & 7.81 & 905 & 114.3 & 4.65 \\
\hline 14 & Jul-19 & $27^{\circ} 56^{\prime} 28^{\prime \prime}, 120^{\circ} 56^{\prime} 16^{\prime \prime}$ & 18.48 & 7.73 & 1,765 & 168.5 & 9.30 \\
\hline 15 & Jul-19 & $27^{\circ} 55^{\prime} 14^{\prime \prime}, 120^{\circ} 59^{\prime} 50^{\prime \prime}$ & 28.46 & 7.72 & 885 & 126.3 & 3.96 \\
\hline 16 & Jul-19 & $27^{\circ} 47^{\prime} 38^{\prime \prime}, 120^{\circ} 46^{\prime} 58^{\prime \prime}$ & 1.87 & 8.43 & 330 & 364.7 & 14.42 \\
\hline 17 & Jul-20 & $27^{\circ} 43^{\prime} 34^{\prime \prime}, 120^{\circ} 44^{\prime} 10^{\prime \prime}$ & 29.27 & 7.91 & 4,475 & 197.2 & 9.03 \\
\hline 18 & Jul-20 & $27^{\circ} 45^{\prime} 51^{\prime \prime}, 120^{\circ} 37^{\prime} 11^{\prime \prime}$ & 14.37 & 7.89 & 650 & 97.3 & 4.33 \\
\hline 19 & Jul-21 & $27^{\circ} 35^{\prime} 33^{\prime \prime}, 120^{\circ} 33^{\prime} 01^{\prime \prime}$ & 7.98 & 7.87 & 845 & 236.9 & 10.55 \\
\hline 20 & Jul-21 & $27^{\circ} 30^{\prime} 24^{\prime \prime}, 120^{\circ} 37^{\prime} 33^{\prime \prime}$ & 32.00 & 7.90 & 1,420 & 142.7 & 5.85 \\
\hline 21 & Jul-22 & $27^{\circ} 23^{\prime} 25^{\prime \prime}, 120^{\circ} 36^{\prime} 30^{\prime \prime}$ & 32.91 & 8.17 & 1,805 & 86.2 & 2.30 \\
\hline 22 & Jul-22 & $27^{\circ} 21^{\prime} 35^{\prime \prime}, 120^{\circ} 32^{\prime} 06^{\prime \prime}$ & 32.64 & 8.14 & 325 & 82.7 & 1.61 \\
\hline 23 & Jul-22 & $27^{\circ} 23^{\prime} 05^{\prime \prime}, 120^{\circ} 33^{\prime} 10^{\prime \prime}$ & 33.89 & 8.01 & 1,120 & 63.1 & 1.47 \\
\hline 24 & Jul-22 & $27^{\circ} 12^{\prime} 37^{\prime \prime}, 120^{\circ} 27^{\prime} 30^{\prime \prime}$ & 33.83 & 7.87 & 370 & 74.0 & 2.16 \\
\hline & Jul-23 & $27^{\circ} 09^{\prime} 48^{\prime \prime}, 120^{\circ} 25^{\prime} 19^{\prime \prime}$ & 32.65 & 7.88 & 140 & 54.8 & 0.83 \\
\hline 26 & Jul-23 & $27^{\circ} 13^{\prime} 44^{\prime \prime}, 120^{\circ} 23^{\prime} 56^{\prime \prime}$ & 31.19 & 7.95 & 137 & 60.5 & 1.06 \\
\hline 27 & Jul-24 & $28^{\circ} 08^{\prime} 22^{\prime \prime}, 120^{\circ} 30^{\prime} 05^{\prime \prime}$ & 0.22 & 7.07 & 335 & 142.6 & 5.67 \\
\hline 28 & Jul-24 & $28^{\circ} 01^{\prime} 42^{\prime \prime}, 120^{\circ} 37^{\prime} 23^{\prime \prime}$ & 0.12 & 7.54 & 605 & 118.7 & 5.30 \\
\hline 29 & Apr-1 & $31^{\circ} 47^{\prime} 27^{\prime \prime}, 121^{\circ} 03^{\prime} 50^{\prime \prime}$ & 0.18 & 7.84 & 95 & 107.3 & 4.19 \\
\hline 30 & Apr-1 & $31^{\circ} 57^{\prime} 38^{\prime \prime}, 120^{\circ} 51^{\prime} 59^{\prime \prime}$ & 0.15 & 7.86 & 50 & 92.4 & 4.10 \\
\hline 31 & Mar-8 & $31^{\circ} 46^{\prime} 13^{\prime \prime}, 120^{\circ} 55^{\prime} 40^{\prime \prime}$ & 0.30 & 7.85 & 39 & 96.4 & 4.38 \\
\hline
\end{tabular}


540 Table 3. Comparison of the optical measurements using three different storage protocols for a river

541 sample collected from Huangpujiang

\begin{tabular}{|c|c|c|c|c|c|c|c|}
\hline \multirow{2}{*}{ Index } & $a_{\mathrm{CDOM}}(300)$ & $S_{\text {CDOM }}(300-500)$ & $F(\mathrm{SR})$ & $F(\mathrm{BT})$ & $F(\mathrm{~A})$ & $F(C)^{\mathrm{a}}$ & \multirow{2}{*}{$\begin{array}{c}F(\mathrm{~A}) / F(\mathrm{BT}) \\
{\left[\mathrm{nm}^{-1} / \mathrm{nm}^{-1}\right]}\end{array}$} \\
\hline & {$\left[\mathrm{m}^{-1}\right]$} & {$\left[\mathrm{nm}^{-1}\right]$} & \multicolumn{4}{|c|}{$\left[\mathrm{nm}^{-1}\right]$} & \\
\hline \multicolumn{8}{|c|}{ stored in cold for less than $48 \mathrm{~h}$ (ave. \pm std., $n=3$ ) } \\
\hline & $5.85 \pm 0.05$ & $0.0167 \pm 0.0001$ & $5.2 \pm 0.1$ & $6.8 \pm 0.3$ & $5.8 \pm 0.2$ & $1.49 \pm 0.05$ & $0.86 \pm 0.01$ \\
\hline $\begin{array}{c}(\mathrm{Ex} / \mathrm{Em}) \max \\
{[\mathrm{nm} / \mathrm{nm}]}\end{array}$ & & & $237.5 / 355$ & $277.5 / 317.5$ & $\begin{array}{c}(255-257.5) / \\
(440-445)\end{array}$ & & \\
\hline \multicolumn{8}{|c|}{ stored in cold $\left(4^{\circ} \mathrm{C}\right)$ for 12 days (ave. \pm std., $n=3$ ) } \\
\hline & $6.09 \pm 0.08$ & $0.0162 \pm 0.0002$ & $4.4 \pm 0.1$ & $6.0 \pm 0.1$ & $5.1 \pm 0.1$ & $41 \pm 0.02$ & $0.86 \pm 0.01$ \\
\hline $\begin{array}{c}(\mathrm{Ex} / \mathrm{Em}) \max . \\
{[\mathrm{nm} / \mathrm{nm}]}\end{array}$ & & & $\begin{array}{c}237.5 / \\
(355-357.5)\end{array}$ & $277.5 / 317.5$ & & & \\
\hline Recovery & $104 \%$ & & $85 \%$ & $88 \%$ & & $95 \%$ & \\
\hline \multicolumn{8}{|c|}{ stored by freezing $\left(-20^{\circ} \mathrm{C}\right)$ for 12 days (ave. \pm std., $n=3$ ) } \\
\hline & $6.31 \pm 0.06$ & $0.0167 \pm 0.0002$ & $4.6 \pm 0.1$ & $6.0 \pm 0.2$ & $5.1 \pm 0.2$ & $1.36 \pm 0.02$ & $0.84 \pm 0.01$ \\
\hline$(\mathrm{Ex} / \mathrm{Em}) \max$. & & & $237.5 /$ & 277.5 & $(260-265) /$ & & \\
\hline$[\mathrm{nm} / \mathrm{nm}]$ & & & $(355-357.5)$ & $(315-317.5)$ & $(435-442.5)$ & & \\
\hline Recovery & $108 \%$ & & $88 \%$ & $88 \%$ & $88 \%$ & $91 \%$ & \\
\hline
\end{tabular}


545 Table 4. Positive correlation coefficients $\left(R^{2}\right)$ between the six parameters of the four fluorescence peak

546 heights of $F(\mathrm{SR}), F(\mathrm{BT}), F(\mathrm{~A})$, and $F(\mathrm{C})$ in EEM contours, and $a_{\mathrm{CDOM}}(300)$ and DOC concentration,

547 for the samples obtained along the Zhejiang coasts (sample 16 is not included in the correlation

548 calculations due to its extremely high values)

\begin{tabular}{|c|c|c|c|c|c|c|}
\hline$R^{2}$ & $F(\mathrm{SR})$ & $F(\mathrm{BT})$ & $F(\mathrm{~A})$ & $F(\mathrm{C})$ & $a_{\mathrm{CDOM}}(300)$ & DOC \\
\hline$F(\mathrm{SR})$ & - & $0.92 * *$ & $0.93 * *$ & $0.94 * *$ & $0.85^{* *}$ & \\
\hline$F(\mathrm{BT})$ & $0.92 * *$ & - & $0.86^{* *}$ & $0.89 * *$ & $0.92 * *$ & $0.85^{* *}$ \\
\hline$F(\mathrm{~A})$ & $0.93 * *$ & $0.86^{* *}$ & - & $0.97 * *$ & $0.88^{* *}$ & $0.77 * *$ \\
\hline$F(C)$ & $0.94 * *$ & $0.89 * *$ & $0.97 * *$ & - & $0.90 * *$ & $0.81 * *$ \\
\hline$a_{\mathrm{CDOM}}(300)$ & $0.85 * *$ & $0.92 * *$ & $0.88 * *$ & $0.90^{* *}$ & & $0.88^{* * *, a}$ \\
\hline DOC & $0.79 * *$ & $0.85^{* *}$ & $0.77 * *$ & $0.81 * *$ & $0.88^{* *,}$, a & - \\
\hline
\end{tabular}

549

**. Correction is significant at the 0.01 level.

550 a. also shown in Fig. 4 but only for 27 samples here. 
552

553

554

555

556

557

558

559

560

561

562

563

564

565

566

567

568

569

570

571

572

573

574

576

577

578

579

580

Figure Captions:

Fig. 1. Map of the study area and the sampling stations, including the 28 samples (1-28) along the Zhejiang coasts and the three (29-31) in the Changjiang river.

Fig. 2. Variation of nutrients and DOC against salinity for the 28 samples along the Zhejiang coasts. The samples are classified into four types denoted by different symbols (see details in Section 3.1). Note the $\log _{10}$ scale in the $y$-axis of Fig. $2 d$.

Fig. 3. PCA results with data from salinity, $\mathrm{DOC}$, and five nutrients (i.e. $\mathrm{SiO}_{3}^{2-}, \mathrm{NO}_{3}^{-}, \mathrm{NH}_{4}^{+}, \mathrm{NO}_{2}^{-}$, and $\mathrm{PO}_{4}{ }^{3-}$ ) (the seven variables) for the 28 samples along the Zhejiang coasts. These samples are then separated into four groups of Type A, B, C, and D. Symbols are as in Fig. 2.

Fig. 4. Correlation between DOC concentration and the CDOM absorption $a_{\mathrm{CDOM}}(300)$ among the 28 samples along the Zhejiang coasts. Symbols are as in Fig. 2.

Fig. 5. Relationship between the CDOM absorption $a_{\mathrm{CDOM}}(300)$ and the spectral slope $S_{\mathrm{CDOM}}(300-500)$ for the 28 samples along the Zhejiang coasts. The solid line shows the correlation for all the 28 data points; whereas the dotted line, only for those of Type C and D. Symbols are as in Fig. 2.

Fig. 6. Representative fluorescence EEM contours for samples of Type A (Fig. 6a and b), B (Fig. 6c and d), C (Fig. 6e and f), and D (Fig. 6g and h) selected from the 28 samples along the Zhejiang coasts. The fluorescence intensities are quantified using Raman Units $\left(\mathrm{nm}^{-1}\right)$. The $(\mathrm{Ex} / \mathrm{Em})_{\max }$ positions for peaks SR, BT, A, and C are denoted in Fig. $6 a$ and b.

Fig. 7. Fluorescence EEM contours for the three samples collected in the Changiiang river. The fluorescence intensities are quantified using Raman Units $\left(\mathrm{nm}^{-1}\right)$. The $(\mathrm{Ex} / \mathrm{Em})_{\max }$ positions for peaks SR, BT, A, and C are denoted in Fig. 7a.

Fig. 8. Variations of the four fluorescence EEM peak heights (i.e. $F(\mathrm{SR}), F(\mathrm{BT}), F(\mathrm{~A})$, and $F(\mathrm{C})$ ) against salinity among the 31 samples (including the 28 samples along the Zhejiang coasts and the three from Changjiang). In each diagram, the data points enclosed by the ellipses are not incorporated into the correlation calculations. Note the breaks in the $y$-axes of Fig. 8a and b.

Fig. 9. Salinity variation in the 28 Zhejiang samples arrayed roughly from north to south along the coastline. Note that samples $2-4$ were collected at the same station and on the same day but at different tidal phases. 


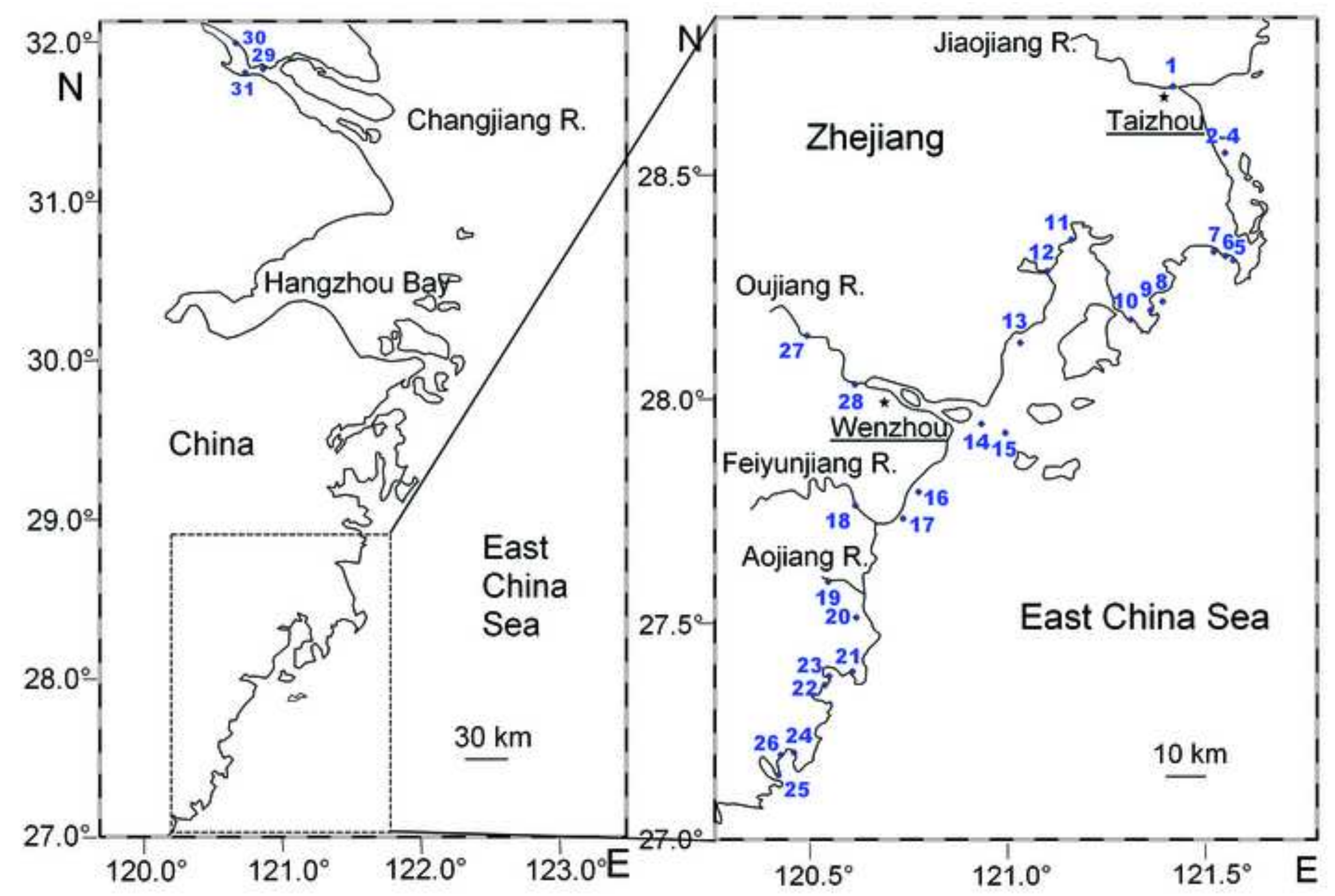



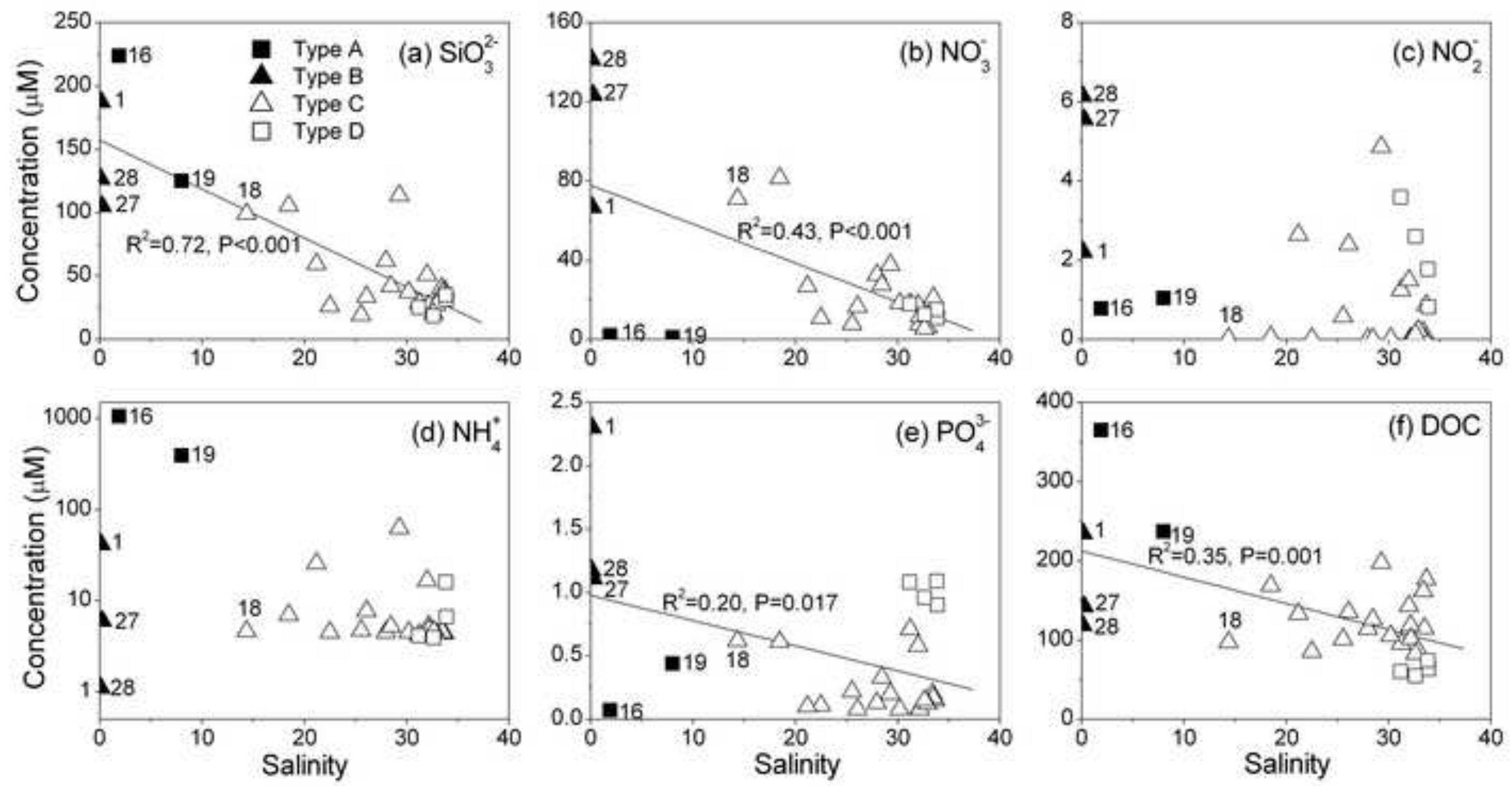


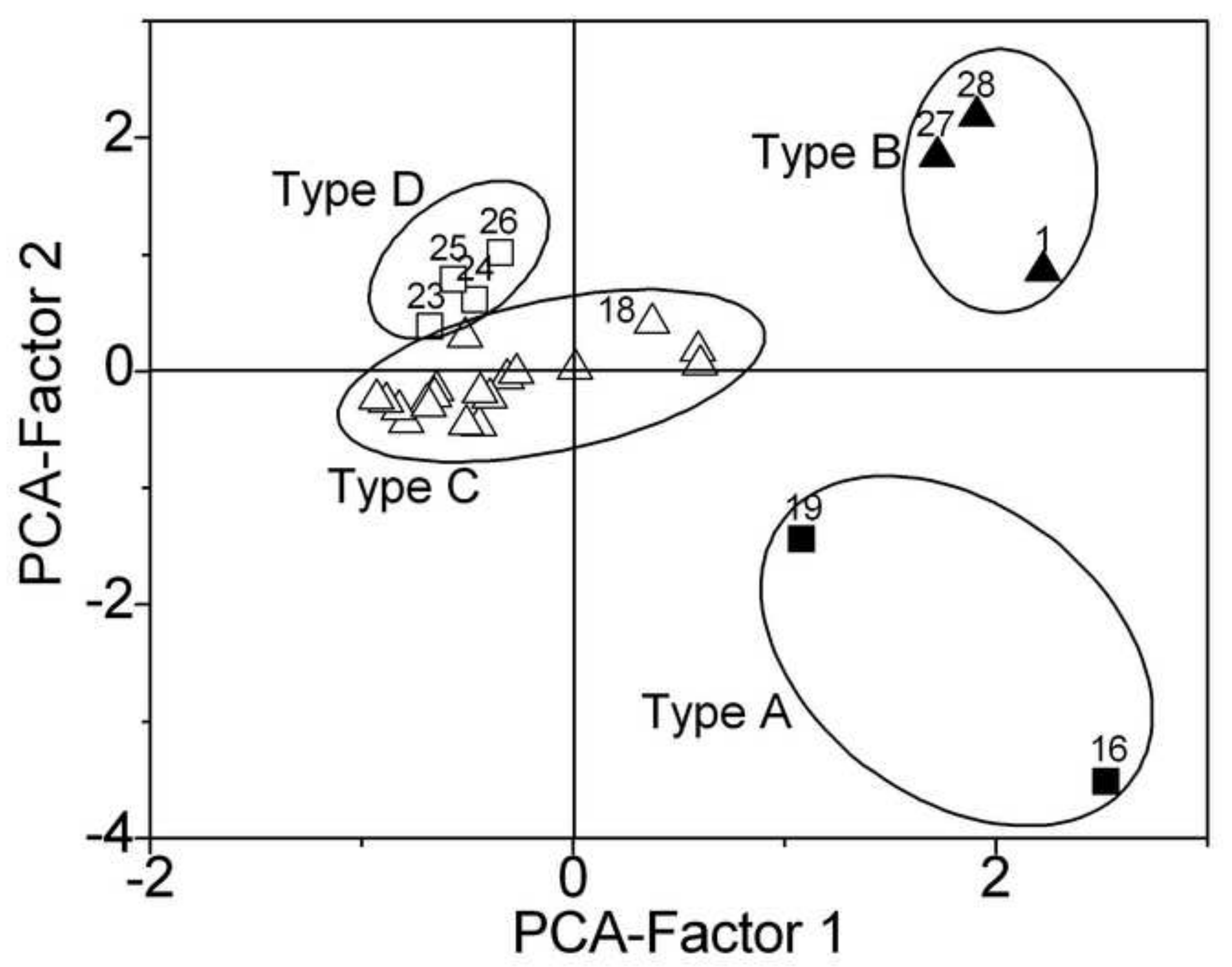




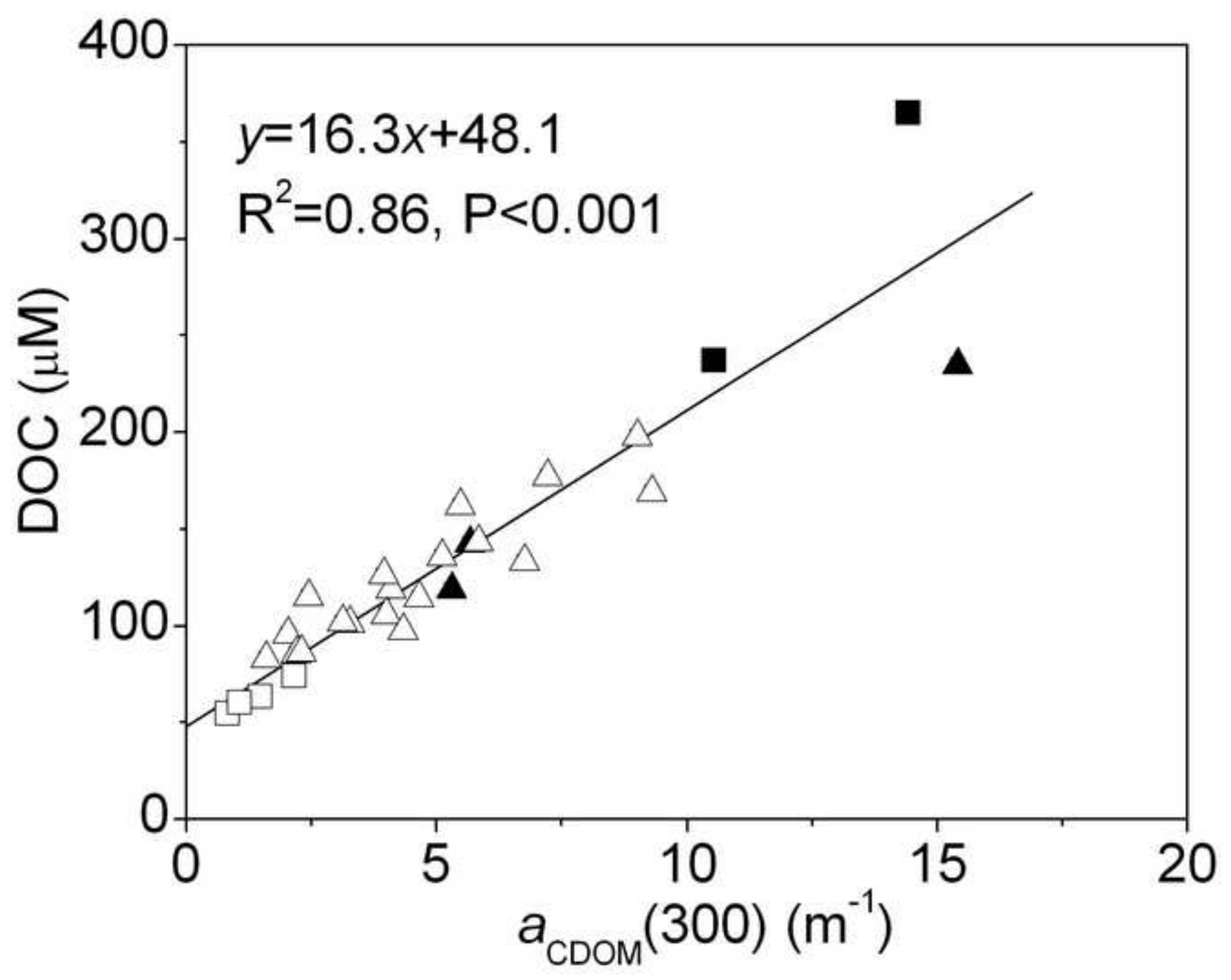




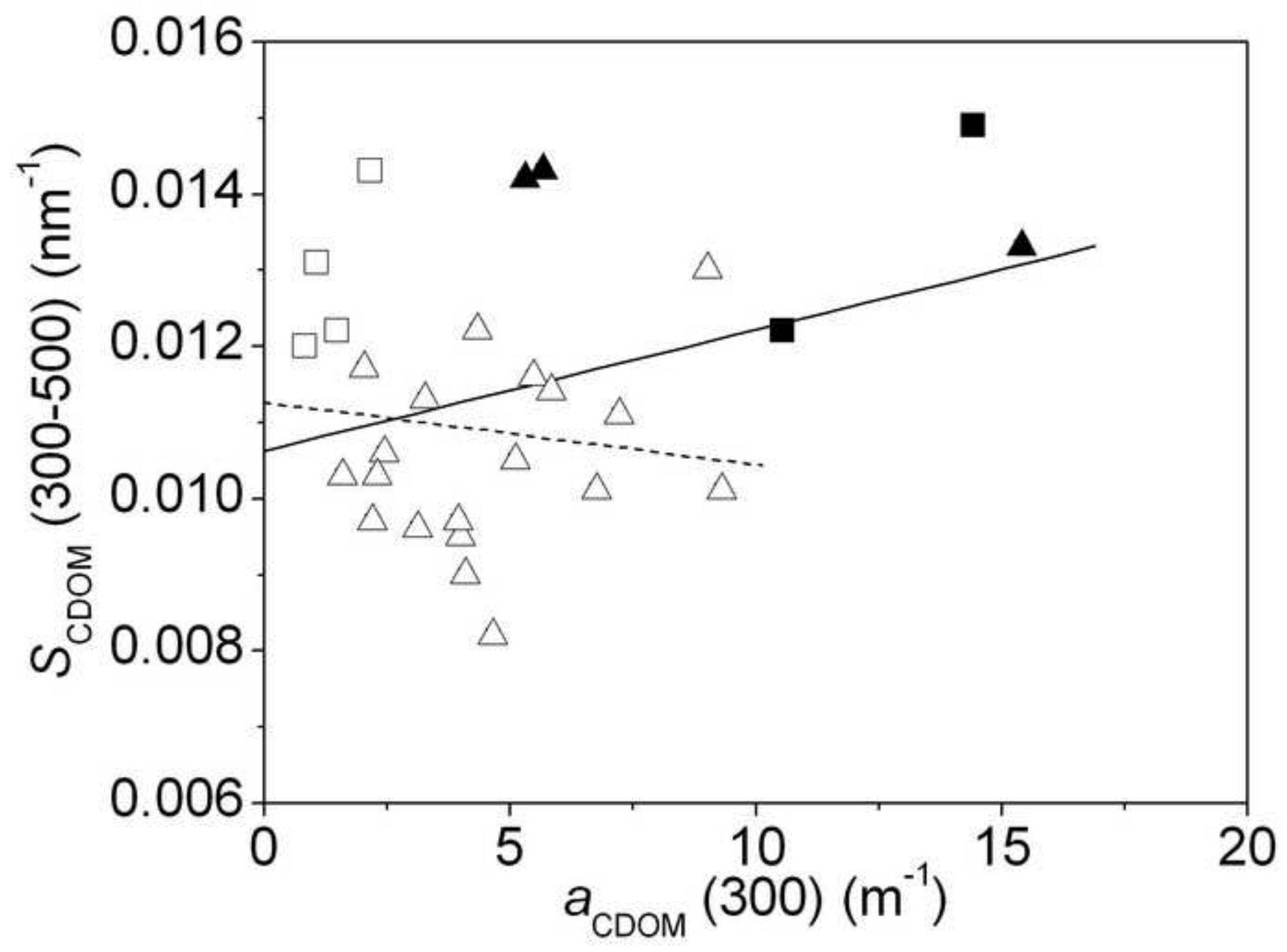



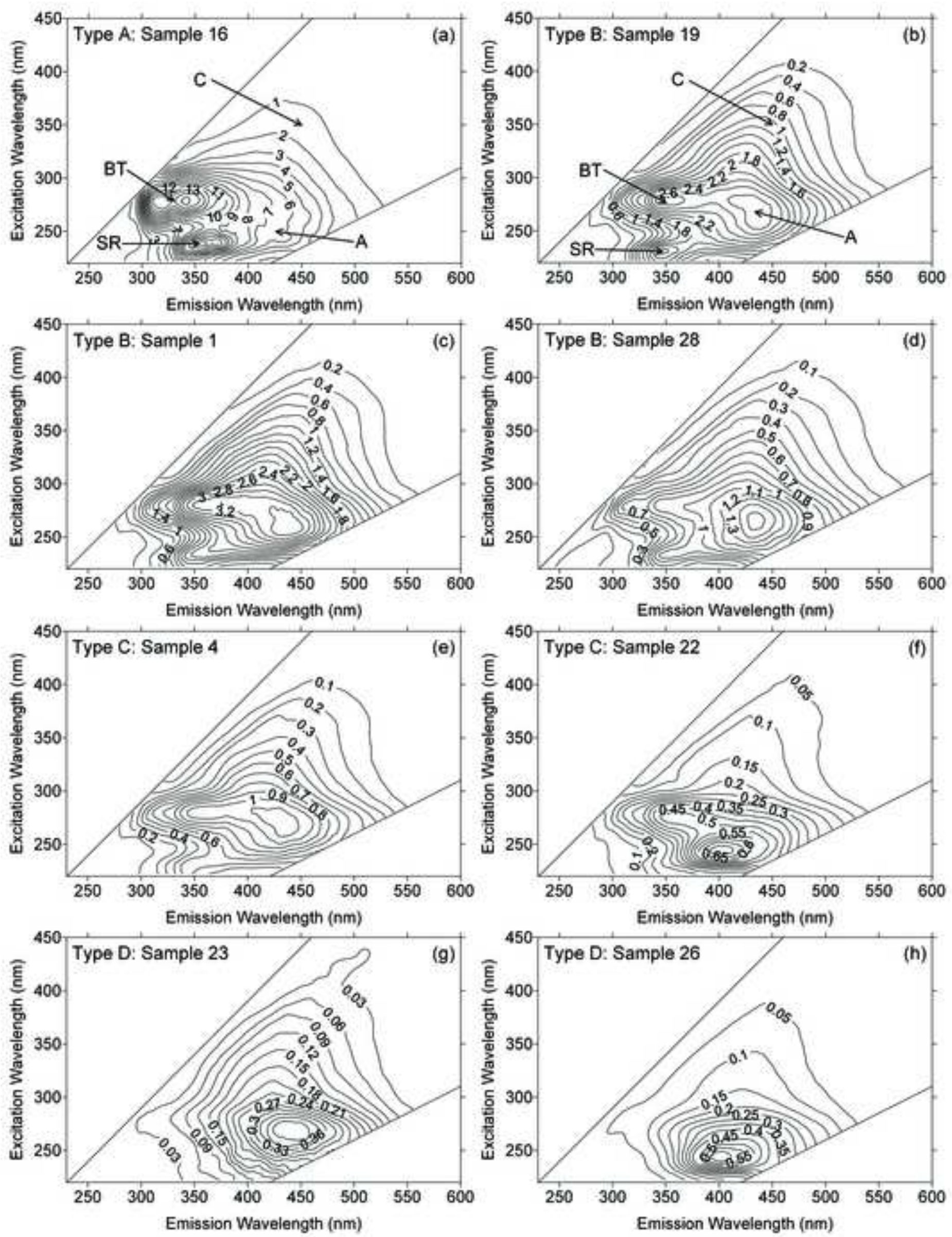

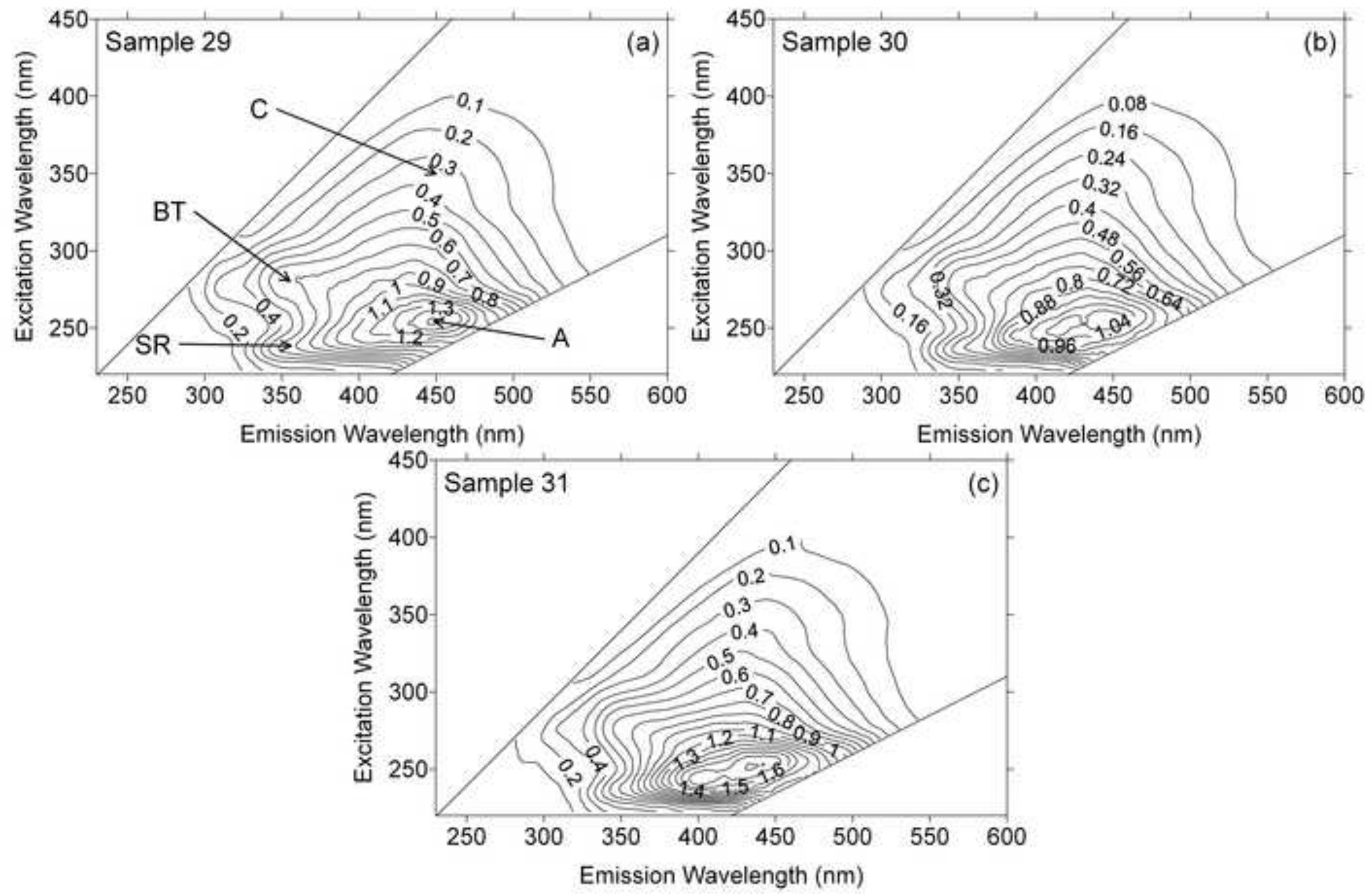

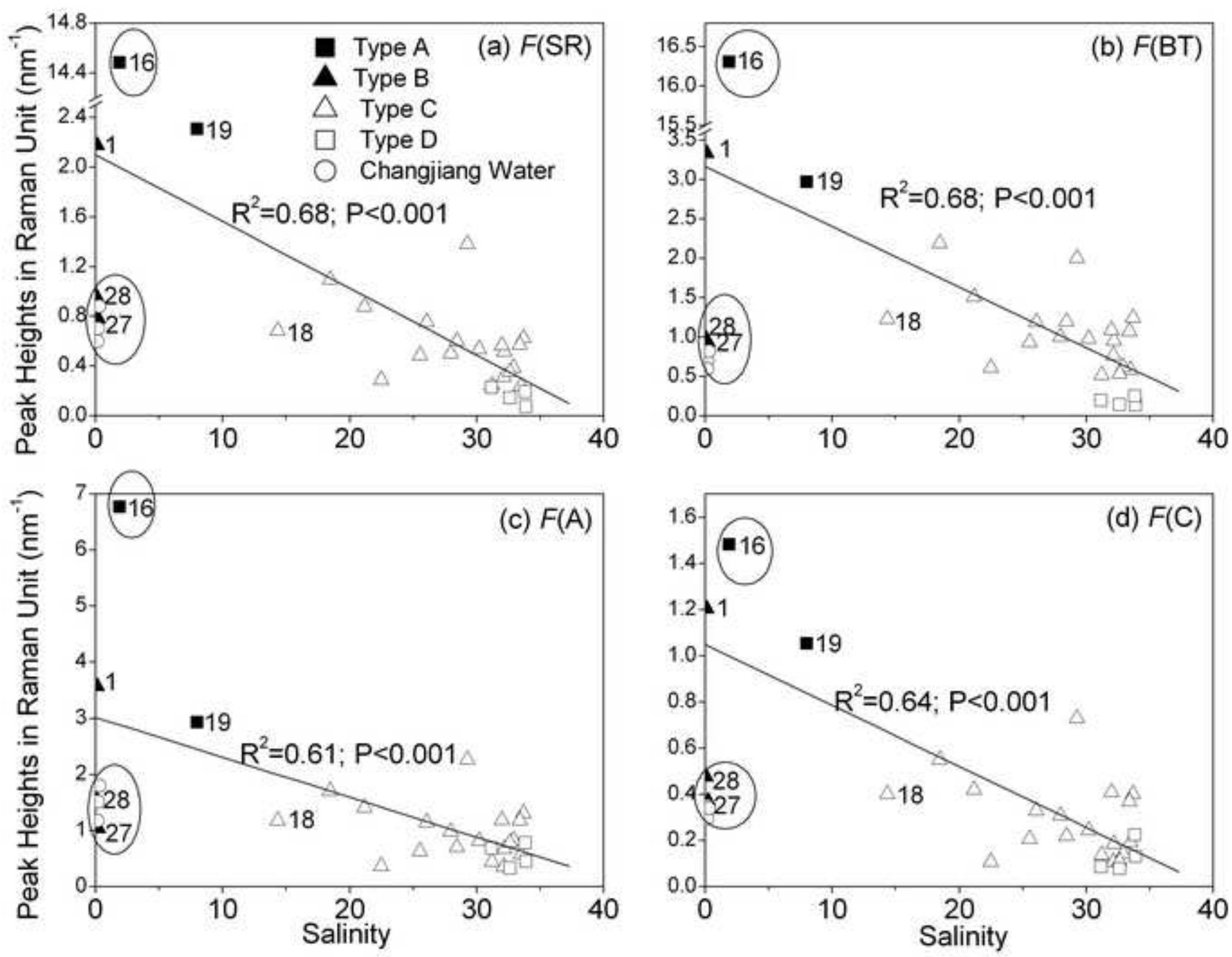


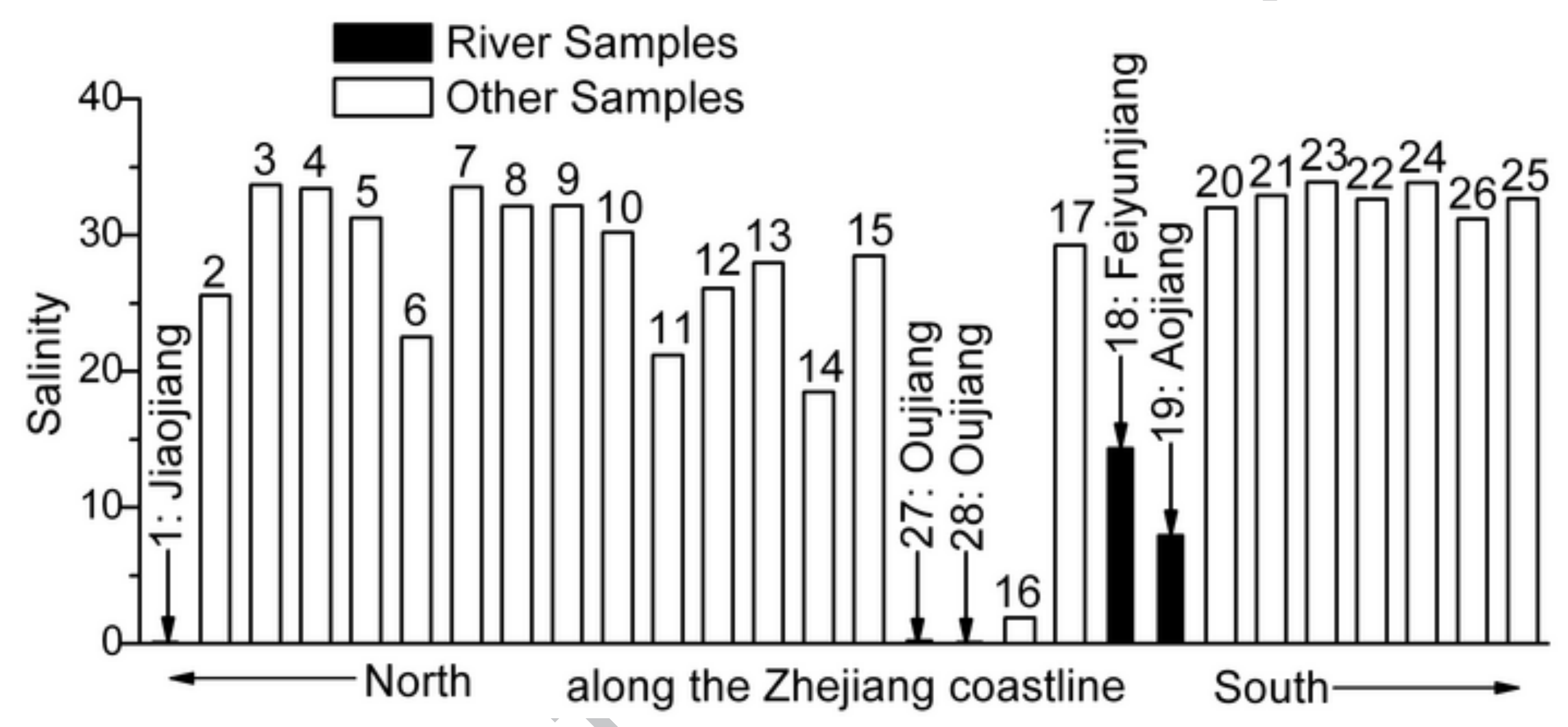

